\title{
Probabilistic analysis of the safety margin assured by shear strength models of stirrup reinforced concrete beams
}

\author{
Roman Jaskulski ${ }^{1, *}$, and Piotr Wiliński ${ }^{1}$ \\ ${ }^{1}$ Warsaw University of Technology, Faculty of Building, Mechanics and Petrochemistry, \\ 17 Łukasiewicza Street, 09-402 Płock, Poland
}

\begin{abstract}
The aim of this study was to assess the safety margin assured by stirrups of reinforced concrete elements subjected to shear. The safety margin was assessed by means of Monte Carlo simulation. The impact of the strength of steel and spacing of stirrups on the results was analysed as well. The used models of shear resistance were taken from the Polish standards PN-84/B-03264 and PN-EN 1992-1-1:2008. The safety margin, expressed as the logarithm of the probability of not achieving the design value of the design ultimate shear capacity was analysed as well as the impact of different assumptions on the obtained results. An attempt was made to assess the "sensitivity" of models to changes of the basic parameters of the probability distribution function of their selected variables.
\end{abstract}

\section{Introduction}

The methods of probabilistic structural analysis enable assessment of the safety margin of existing structures and the design of structures with a specific safety margin. Inter alia the work [1] is devoted to the second goal of probabilistic analysis. The methods can also be used to determine the safety margin of the shear strength models included in the standards. Full model analysis combined with their comparison is a complex and laborious task due to significant differences in the assumptions of individual models, as well as variations in their parameters. Therefore, the authors of this paper have set themselves a slightly less complex task, which is reduced to the parallel analysis of two significantly differing normative models. This analysis was not intended to directly compare selected models and the safety margin assured by them, but to compute safety margins of the same structure element using selected models with possibly similar assumptions, and to determine the impact of changing the assumptions on the level of its safety margin. Having independently prepared software with built-in models of shear strength of stirrup reinforced concrete element, an analysis of selected models was conducted in terms of their "sensitivity" to change the parameters of distribution of selected variables.

*Corresponding author: Roman.Jaskulski@pw.edu.pl 
This topic has not been widely taken up so far. Results of probabilistic analysis of the shear strength of elements cross-sections was presented i.a. in [2-4]. Some attempts of this kind of probabilistic were also undertaken in [5]. Due to the complexity of the modelling of shear strength in reinforced concrete elements, the paper is limited to the models of shear strength of rectangular cross-section beam reinforced with single stirrups perpendicular to the axis of the element. Two models derived from completely different assumptions were selected for analysis. One of them was included in PN-84/B-03264 (denoted further as PN-84) [6], which was a standard used for a long time in Poland, and the second one is included in the currently used Polish standard PN-EN 1992-1-1:2008 (denoted further as EC-2) [7].

\section{Analyzed shear strength models}

In the literature a large number of models of shear resistance of reinforced concrete elements are described (i.a. in [8,9]). In this work authors limited their choice to two models based on different concepts and assumptions. Model in the PN-84 standard is based on the Boriszanski method [10], developed in the former USSR. In this model the destruction of the element is due to the rotation of the part of a beam cut-off by a diagonal crack around the point located over the end of the crack. More detailed description of this method can be found in $[8,9,11]$. The model included in EC-2 standard is based on the truss analogy and was originally developed by Mörsch [12]. The Kupfer concept [13] was finally adopted in standards which is the development of the classic truss method.

\subsection{The PN-84 model}

The following formulas were given in [6] and explained in $[11,14]$. The ultimate shear force in the case of elements reinforced only with stirrups (Qsb) is described by the formula:

$$
Q_{s b}=\sqrt{4 \cdot \beta_{s} \cdot R_{b} \cdot q_{s} \cdot b \cdot h_{o}^{2}}-R_{a s} \cdot F_{s}
$$

where: $Q_{s b}$ is the ultimate shear force carried by concrete and stirrups, $\beta_{s}$ is a coefficient dependent on how the element is supported and loaded, $R_{b}$ is the design compressive strength of concrete, $q_{s}$ is the ultimate force carried by stirrups (per unit length), $b$ is the cross-section width, $h_{o}$ is the effective height of the cross-section, $R_{a s}$ is the design tensile strength of steel of the stirrups equal $80 \%$ of design yield strength of steel and $F_{s}$ is the cross-section area of one stirrup.

The ultimate force $q_{s}$ is calculated using formula:

$$
q_{s}=\frac{R_{a s} \cdot F_{s}}{s}
$$

where $s$ is the spacing of stirrups.

\subsection{The EC-2 model}

The design shear force carried by the stirrups $\left(V_{R d, s}\right)$ in the elements with vertical shear reinforcement shall be calculated using the formula (3) which is given in [7]. And the sole model is described in [15]. 


$$
\mathrm{V}_{\mathrm{Rd}, \mathrm{s}}=\frac{\mathrm{A}_{\mathrm{sw}}}{\mathrm{s}} \cdot \mathrm{z} \cdot \mathrm{f}_{\mathrm{ywd}} \cdot \cot \theta
$$

In the formula (3) $V_{R d, s}$ is design shear force carried by the shear reinforcement, $A_{s w}$ is the cross-section area of the stirrups which are located in one plane perpendicular to the axis of the element, $z$ is the shear zone height (can be assumed as $0,9 \cdot d$ ), $d$ is effective height of the cross-section, $f_{y w d}$ is the design yield strength of steel of stirrups, $\cot \theta$ is cotangent of angle $\theta$ of inclination of compressed concrete struts (arbitrarily taken from interval $<1,2>$ ), $s$ is spacing of stirrups perpendicular to the axis of the element.

\section{Assumptions adopted in calculations}

The variables in the formulas (1), (2) and (3) were divided into two groups. The first included: the spacing of the stirrups, compressive strength of concrete, yield strength of steel and the cotangent $\theta$. For these variables, at least two different variants of their distribution parameters were used in the simulations. The second group of variables included: the height and width of the element cross-section, thickness of the reinforcement cover and the cross-section area of the single stirrup. In this group, one variant of distribution parameters was used in all simulations.

Table 1. Distribution parameters of the first group of variables.

\begin{tabular}{|c|c|c|c|c|c|c|}
\hline Variant & Parameter & $\mathbf{x}_{\text {nom }}$ & $\mathbf{x}_{\mathbf{m}}$ & $\sigma_{\mathbf{X}}$ & $v_{\mathbf{X}}$ & $\begin{array}{c}\text { Type of } \\
\text { distibution }\end{array}$ \\
\hline SM & \multirow{2}{*}{ stirrups spacing $s_{l}[\mathrm{~mm}]$} & 70 & 70 & 5 & $7,14 \%$ & \multirow{2}{*}{ normal } \\
\hline SD & & 150 & 150 & 5 & $3,57 \%$ & \\
\hline FM & \multirow{2}{*}{ yield strength of steel $f_{y w}[\mathrm{MPa}]$} & 210 & 341,6 & 10,25 & $3,0 \%$ & normal \\
\hline FD & & 210 & 341,6 & 44,38 & $13,0 \%$ & normal \\
\hline $\mathrm{C} 16 / 20 \mathrm{NM}$ & \multirow{8}{*}{$\begin{array}{l}\text { compressive strength of concrete } \\
f_{c}[\mathrm{MPa}]\end{array}$} & 10,8 & 21,30 & 0,85 & $4.0 \%$ & \multirow{4}{*}{ normal } \\
\hline $\mathrm{C} 40 / 50 \mathrm{NM}$ & & 26,7 & 53,20 & 2,13 & $4,0 \%$ & \\
\hline C16/20ND & & 10,8 & 26,20 & 4,19 & $16,0 \%$ & \\
\hline $\mathrm{C} 40 / 50 \mathrm{ND}$ & & 26,7 & 65,50 & 10,05 & $15,3 \%$ & \\
\hline C16/20LM & & 10,8 & 21,30 & 0,85 & $4,0 \%$ & \multirow{4}{*}{ lognormal } \\
\hline $\mathrm{C} 40 / 50 \mathrm{LM}$ & & 26,7 & 53,20 & 2,13 & $4,0 \%$ & \\
\hline $\mathrm{C} 16 / 20 \mathrm{LD}$ & & 10,8 & 26,20 & 4,19 & $16,0 \%$ & \\
\hline $\mathrm{C} 40 / 50 \mathrm{LD}$ & & 26,7 & 65,50 & 10,05 & $15,3 \%$ & \\
\hline $\mathrm{T} 1$ & \multirow{2}{*}{$\cot \theta[-]$} & 1 & - & - & - & --- \\
\hline $\mathrm{T} 2$ & & 2 & - & - & - & --- \\
\hline
\end{tabular}


A rectangular cross-section of nominal dimensions: $b=0.30 \mathrm{~m}$ and $h=0.60 \mathrm{~m}$ was adopted in simulations. The thickness of the reinforcement cover $a_{1}=0.05 \mathrm{~m}$ was assumed. The distribution parameters of the above variables were assumed according to the recommendations in $[16,17]$. Values of steel yield strength distribution parameters were taken from [11]. The values given therein have been verified in own tests and the study description with results is given in [18]. After analysing the results of the own research it was decided to assume two values of coefficient of variation of yield strength of stirrup steel: $3 \%$ and $13 \%$. It was assumed that the cross-section would be reinforced with stirrups with a diameter of $8 \mathrm{~mm}$, so the mean and nominal value of the cross-sectional area of the single stirrup was assumed to be $1.0 \mathrm{~cm}^{2}$. Cross-sectional variation coefficient was assumed to be $3 \%$ according to [11]. Two nominal values of stirrup spacing were assumed: $0.07 \mathrm{~m}$ and $0.15 \mathrm{~m}$. The mean values of stirrup spacing were assumed to be equal to the nominal values and the standard deviation was assumed in both cases at $0.005 \mathrm{~m}$.

Four sets of compressive strength distribution parameters were adopted. Two of them corresponded to the strength class $\mathrm{C} 16 / 20$ and two class C40/50. Within one class of concrete, the values of variation coefficients were additionally varied. The $\cot \theta$ values were assumed a deterministic variables as $\cot \theta=1$ and $\cot \theta=2$.

Normal distribution was used to for all random variables as a base one. Some additional simulations were made using lognormal distribution of compressive strength of concrete. The variable distribution parameters are given in Tables 1 and 2.

Table 2. Distribution parameters of the second group of variables.

\begin{tabular}{|l|c|c|c|c|c|}
\hline \multicolumn{1}{|c|}{ Parameter } & $\mathbf{x}_{\mathbf{n o m}}$ & $\mathbf{x}_{\mathbf{m}}$ & $\boldsymbol{\sigma}_{\mathbf{X}}$ & $\boldsymbol{v}_{\mathbf{X}}$ & $\begin{array}{c}\text { Type of } \\
\text { distibution }\end{array}$ \\
\hline width $b[\mathrm{~mm}]$ & 300 & 300,9 & 5,8 & $1,93 \%$ & normal \\
\hline height $h[\mathrm{~mm}]$ & 600 & 601,8 & 7,6 & $1,26 \%$ & normal \\
\hline concrete cover $a_{1}[\mathrm{~mm}]$ & 50 & 50 & 3 & $6,0 \%$ & normal \\
\hline stirrups cross-section area $A_{s w}\left[\mathrm{~cm}^{2}\right]$ & 1,00 & 1,00 & 0,03 & $3,0 \%$ & normal \\
\hline
\end{tabular}

\section{Monte Carlo simulations}

The simulation program developed by Jaskulski [1] was used. The program generates random variable values based on a pseudorandom number generator with a uniform distribution on the interval $(0,1)$, which is an integral part of the Pascal language. The program allows to calculate the shear strength as described above, and also gives the value of the reliability index $\beta_{R}$ defined by the formula (4)

$$
\beta_{\mathrm{R}}=\frac{\mathrm{R}_{\mathrm{m}}-\mathrm{R}_{\mathrm{d}}}{\sigma_{\mathrm{R}}}
$$

where $R_{m}$ is the average shear strength (based on the simulation), $R_{d}$ is design shear strength, $\sigma_{R}$ is standard deviation of shear strength (based on the simulation). The design strength $R_{d}$ is entered as a parameter when starting the software. The value $\beta_{R}$ serves as the boundary of the integral (5) calculating the probability $p_{f}$ obtaining the value of the strength lower than the calculated value $R_{d}$. Integrated function is the NG probability distribution described i.a. in [19] 


$$
\mathrm{p}_{\mathrm{f}}=\int_{-\infty}^{-\beta_{R}} f_{N G}(t) d t
$$

In the formula (5) $f_{N G}$ is the function of $\mathrm{NG}$ distribution of the random variable, $t$ is normalized random variable.

The simulations were divided into two groups: basic simulations and so called "zero" simulations. In the basic simulations, all random variables were generated according to the probability distributions assigned to them. The "zero" simulations determined the effect of the random variation of each variable individually on the safety margin of the element cross section. For this purpose, only one selected variable was generated randomly and the remaining values remained constant during simulation (average values were assumed). The exception to this rule was the effective height $d$ where two variables were assumed to be randomly variable: the section height $h$ and the thickness of the concrete cover $a_{l}$. In the "zero" simulations, only one variant of distribution parameters was used for each variable. The values of the parameters accepted in the null simulations are summarized in Table 3.

Table 3. Random variables distribution parameters in the "zero" simulations.

\begin{tabular}{|l|c|c|c|c|c|}
\hline \multicolumn{1}{|c|}{ Parameter } & $\mathbf{x}_{\mathbf{n o m}}$ & $\mathbf{x}_{\mathbf{m}}$ & $\boldsymbol{\sigma}_{\mathbf{X}}$ & $\boldsymbol{v}_{\mathbf{X}}$ & $\begin{array}{c}\text { Type of } \\
\text { distribution }\end{array}$ \\
\hline width $b[\mathrm{~mm}]$ & 300 & 300,9 & 5,8 & $1,93 \%$ & normal \\
\hline height $h[\mathrm{~mm}]$ & 600 & 601,8 & 7,6 & $1,26 \%$ & normal \\
\hline concrete cover $a_{1}[\mathrm{~mm}]$ & 50 & 50 & 3 & $6,0 \%$ & normal \\
\hline yield strength of steel $f_{y w}[\mathrm{MPa}]$ & 210 & 341,6 & 44,38 & $13,0 \%$ & normal \\
\hline stirrups cross-section area $A_{s w}\left[\mathrm{~cm}^{2}\right]$ & 1,00 & 1,00 & 0,03 & $3,0 \%$ & normal \\
\hline stirrups spacing $s_{1}[\mathrm{~mm}]$ & 70 & 70 & 5 & $7,14 \%$ & normal \\
\hline compressive strength of concrete $f_{c}[\mathrm{MPa}]$ & 10,8 & 21,30 & 0,85 & $4.0 \%$ & normal \\
\hline cot $\theta[-]$ & 1 & - & - & - & --- \\
\hline
\end{tabular}

For each data set, both in the basic and the "zero" simulations, five independent simulations of 2,000,000 randomly generated values for each random variable were performed. The results of these five simulations were then averaged. The detailed results are included in [S].

\section{Results and discussion}

Some difficulties in analysing the obtained results are due to the fact that both used models have only two common parameters that were used in more than one variant: the spacing of the stirrups and the yield strength of steel. Additionally, for each of these models there is a parameter that is not present in the second model. These are the compressive strength of concrete in the PN-84 model and the angle of inclination of compressed concrete struts in the EC-2 model. This makes it difficult to interpret the identified differences. Therefore, the results obtained, with the exception of mean ultimate shear strength, were analyzed in parallel without direct comparing them.

Mean values of shear strength obtained from the simulation is given in Table 4. The results obtained using the lognormal distribution were omitted because the type of distribution did not influence the obtained mean values. Analysis of mean values of shear 
strength leads to the conclusion that with the stirrup spacing of $0.07 \mathrm{~m}$, the least load capacity (calculated using the model EC-2 at $\cot \theta=1$ ) is almost five times lower than the maximum value (calculated according to $\mathrm{PN}-84$ model assuming C40/50 concrete and greater variability of its strength). When the spacing increases to $0.15 \mathrm{~m}$, the difference between models is up to almost seven times. Such great differences result primarily from the fact that the PN-84 model, in contrast to the EC-2, assumes the cooperation of concrete in shear force carrying. The adoption of the C16/20 concrete and the more favourable value $\cot \theta=2$ in the EC-2 model reduces the advantage of the first of these models to $33 \%$.

Table 4. Mean values of shear strength.

\begin{tabular}{|c|c|c|c|c|c|c|c|}
\hline \multirow{3}{*}{$\begin{array}{c}\text { Spacing } \\
\text { of } \\
\text { stirrups } \\
\text { [m] }\end{array}$} & \multirow{3}{*}{$\begin{array}{c}\text { Steel } \\
\text { yield } \\
\text { strength } \\
\text { variation } \\
\text { variant }\end{array}$} & \multicolumn{2}{|c|}{$\begin{array}{c}\mathrm{V}_{\mathrm{R}, \mathrm{s}} \\
\text { (the EC-2 } \\
\text { model) }\end{array}$} & \multicolumn{4}{|c|}{$\begin{array}{c}\mathrm{Q}_{\text {sb }} \\
\text { (the } \mathrm{PN-84} \text { model) }\end{array}$} \\
\hline & & \multirow{2}{*}{ T1 } & \multirow{2}{*}{$\mathbf{T} 2$} & \multicolumn{2}{|c|}{$\mathrm{C} 16 / 20$} & \multicolumn{2}{|c|}{$\mathrm{C} 40 / 50$} \\
\hline & & & & NM & ND & NM & ND \\
\hline \multirow{2}{*}{0,07} & FM & 244 & 487 & 650 & 721 & 1043 & 1157 \\
\hline & FD & 244 & 487 & 648 & 720 & 1041 & 1154 \\
\hline \multirow{2}{*}{0,15} & FM & 113 & 226 & 435 & 483 & 703 & 780 \\
\hline & FD & 113 & 226 & 434 & 482 & 702 & 779 \\
\hline
\end{tabular}

The level of the safety margin of the concrete element subjected to shear forces obtained in the simulation was also analysed. The partial reliability exponent $\Delta_{R}$ defined by the formula (6) was used for this purpose.

$$
\Delta_{R}=-\log \left[p_{f}\left(R \leq R_{d}\right)\right]
$$

With such a useful measure of safety margin, the analysis is convenient. An alternative is to use the probability values pf or the reliability index $\beta_{R}$. Both of these measures have their limitations. The reliability index $\beta_{R}$ does not allow for the impact of shear strength distribution skewness to be taken into account, which may sometimes significantly influence the level of safety margin. On the other hand, using of the probability values $p_{f}$ is impracticable because of the differences which often reach more than a dozen orders of magnitude. This makes it difficult for direct comparisons and reception of results. The values of the partial reliability exponent $\Delta_{R}$ are presented in Table 5.

Table 5. Values of partial reliability index $\Delta_{R}$.

\begin{tabular}{|c|c|c|c|c|c|c|c|c|c|c|c|}
\hline \multirow{3}{*}{$\begin{array}{c}\text { Spacing } \\
\text { of } \\
\text { stirrups } \\
{[\mathrm{m}]} \\
\end{array}$} & \multirow{3}{*}{$\begin{array}{l}\text { Steel } \\
\text { var. }\end{array}$} & \multicolumn{2}{|c|}{$\mathbf{V}_{\mathrm{R}, \mathrm{s}}$} & \multicolumn{4}{|c|}{$\mathbf{Q}_{\mathrm{sb}}$ (Normal) } & \multicolumn{4}{|c|}{$\mathbf{Q}_{\mathrm{sb}}$ (Lognormal) } \\
\hline & & \multirow{2}{*}{ T1 } & \multirow{2}{*}{ T2 } & \multicolumn{2}{|c|}{ C16/20 } & \multicolumn{2}{|c|}{ C40/50 } & \multicolumn{2}{|c|}{ C16/20 } & \multicolumn{2}{|c|}{ C40/50 } \\
\hline & & & & NM & ND & NM & ND & LM & LD & LM & LD \\
\hline \multirow{2}{*}{$\mathbf{0 , 0 7}$} & $\mathbf{F M}$ & 5,78 & 11,7 & 18,2 & 4,66 & 18,7 & 5,09 & 18,2 & 7,35 & 18,7 & 7,95 \\
\hline & FD & 2,38 & 2,38 & 7,99 & 5,26 & 7,97 & 5,53 & 7,99 & 5,44 & 7,97 & 5,69 \\
\hline \multirow{2}{*}{0,15} & FM & 5,79 & 11,7 & 30,4 & 4,24 & 31,1 & 4,48 & 30,4 & 8,03 & 31,1 & 8,82 \\
\hline & FD & 2,63 & 2,63 & 5,17 & 5,62 & 5,11 & 5,93 & 5,20 & 5,83 & 5,13 & 6,12 \\
\hline
\end{tabular}

Analysis of partial reliability exponent values shows that the level of safety margin achieved for different data variants in the EC-2 model is less varied than that of the PN-02 model. Given the high variability of the average yield strength of steel, the safety margin 
determined using the EC-2 model is lower than that of the PN-02 model. On the other hand, with the low variability of the yield strength of steel, the obtained safety margin according to the EC-2 model is within the range obtained using the PN-02 model.

For the EC-2 model, the calculated value of the partial reliability exponent depends on all analysed variables occurring in more than one variant. In the case of low variability of yield strength of steel (the FM variant), the obtained exponent value was 2 to almost 5 times higher than the value obtained for high variability of the steel yield strength (the FD variant). The stirrup spacing did not affect the results, and the higher $\cot \theta$ resulted in than double increase of the partial reliability exponent. This may be due to the more favourable positioning of the concrete compressive struts relative to the shear force direction at the higher $\cot \theta$ value. In the case of high variability of higher variability of yield strength of steel (the FD variant), the greater stirrup spacing resulted in an increase in the partial reliability exponent, and this time the $\cot \theta$ value did not affect the results. More dense stirrups spacing in the element causes the increase in steel shear in the assuring of the element's safety margin, thus the high variability of its yield strength is more likely to translate into variability in shear strength and as a result, the safety margin decrease.

Analysis of the partial reliability exponent values obtained with the PN-02 model shows that the combination of the low variability of steel strength variant (FM) with low variability in compressive strength of concrete results in a significant increase in the partial reliability exponent (from more than 2 to almost 6 times) in comparison to the FD variant. This effect is not dependent on the type of concrete strength distribution. With high variability of compressive strength of concrete, two tendencies can be distinguished, depending on the type of the distribution adopted. In the case of normal distribution, the partial reliability exponent decreases by a maximum of $30 \%$, whereas in the case of lognormal distribution it increases by approximately $40 \%$.

Using two different types of concrete strength distribution is reflected in the differences in the value of the partial reliability factor in the PN-02 model at a moderate level, if analysed together with the FD variant. In the case of low variability in concrete strength differences are practically negligible. In the case of low variability of the steel yield strength (FM), combined with the high variability of concrete strength, the effect of the type of concrete strength distribution is revealed. The partial reliability exponent is almost doubling, which may indicate a specific case of synergy.

Assuming of different values of the coefficient of variation of concrete strength, coupled with the high variability of the yield strength of steel, leads to distinct differences in the estimated safety level. There are two different tendencies here. Assuming the smaller spacing of stirrups and increasing the coefficient of variation in concrete strength fourfold decreases the $\Delta_{R}$ value by approximately $35 \%$. On the other hand, assuming the higher spacing of stirrups and increasing the coefficient of variation of concrete strength fourfold leads to an increase of $\Delta_{R}$ by a maximum of about $30 \%$.

In addition to the mean values also the coefficient of skewness $a_{R}$ was calculated in simulations. It is important in probabilistic estimating of safety margin by integrating the ultimate strength distribution. If the strength distributions has skewness which significantly differs from zero, then omission of this parameter in calculating of safety margins results in incorrect estimation. The values of the coefficient of skewness $\Delta_{R}$ are presented in Table 6 .

Analysis of values of the skewness coefficient shows that in the case of the PN-02 model, assuming a high steel yield strength variation (FD), in most cases the skewness coefficient is close to zero. Derogation from this rule only occurred when assuming C40/50 concrete and lognormal distribution of its strength. Under such assumptions, the skewness coefficient ranged from 0.23 to 0.27 . There was also a tendency observed that the value of the coefficient of skewness decreases as the spacing of the stirrup increases. 
Table 6. Values of coefficient of skewness $a_{R}$.

\begin{tabular}{|c|c|c|c|c|c|c|c|c|c|c|c|}
\hline \multirow{3}{*}{$\begin{array}{c}\text { Spacing } \\
\text { of } \\
\text { stirrups } \\
\text { [m] }\end{array}$} & \multirow{3}{*}{$\begin{array}{l}\text { Steel } \\
\text { var. }\end{array}$} & \multicolumn{2}{|c|}{$\mathbf{V}_{\mathrm{R}, \mathrm{s}}$} & \multicolumn{4}{|c|}{$\mathbf{Q}_{\mathrm{sb}}$ (Normal) } & \multicolumn{4}{|c|}{$\mathbf{Q}_{\mathrm{sb}}$ (Lognormal) } \\
\hline & & \multirow{2}{*}{ T1 } & \multirow{2}{*}{$\mathbf{T} 2$} & \multicolumn{2}{|c|}{ C16/20 } & \multicolumn{2}{|c|}{$\mathbf{C} 40 / 50$} & \multicolumn{2}{|c|}{ C16/20 } & \multicolumn{2}{|c|}{$\mathbf{C} 40 / 50$} \\
\hline & & & & NM & ND & NM & ND & LM & LD & $\mathbf{L M}$ & LD \\
\hline \multirow{2}{*}{$\mathbf{0 , 0}$} & FM & 0,37 & 0,37 & 0,22 & 0,22 & $-0,04$ & $-0,02$ & 0,23 & 0,23 & 0,28 & 0,28 \\
\hline & FD & 0,24 & 0,24 & 0,07 & 0,06 & 0,09 & 0,10 & 0,07 & 0,06 & 0,27 & 0,26 \\
\hline \multirow{2}{*}{0,15} & FM & 0,16 & 0,16 & 0,09 & 0,09 & $-0,13$ & $-0,12$ & 0,11 & 0,11 & 0,25 & 0,24 \\
\hline & FD & 0,09 & 0,09 & $-0,04$ & $-0,04$ & 0,03 & 0,03 & $-0,04$ & $-0,04$ & 0,25 & 0,23 \\
\hline
\end{tabular}

Assuming the low variation of the yield strength of steel (FM), the value of this factor increases significantly (almost fourfold) compared to the high variation (FD) variant. Derogation from this rule only occurred when concrete class C40/50 was assumed. In the case of assumption of the normal distribution of concrete strength in the simulations, the values of the coefficient of change the sign and grow or decrease almost fourfold. In the case of assumption of the lognormal distribution of concrete strength, the skewness coefficients slightly increase. Also the tendency of decrease of the coefficient of skewness with the increasing stirrup spacing was observed (except for the assumption of C40/50 concrete with normal distribution of its strength).

Also in the case of the EC-2 model, the coefficient of skewness obtained by assuming the larger stirrup spacing is smaller, with the differences here being very clear. With the small stirrup spacing, the coefficient of variation was approximately 2.5 times greater than that for the larger span, and this ratio is independent of the variability of the steel yield strength. The value of the coefficient of skewness also does not depend on the assumed value of the $\cot \theta$.

The last analyzed dependency was the influence of the variability of the individual parameters of the shear strength models on the coefficient of variation of the shear strength distribution obtained by the simulation. For this purpose, the previously mentioned "zero" simulations were performed. For the purpose of the analysis, the values of three coefficients of variation were calculated (and are presented in Table 7):

Table 7. Results of the "zero" simulations.

\begin{tabular}{|c|c|c|c|c|c|c|}
\hline \multirow{2}{*}{ Model } & \multirow{2}{*}{ Variable } & \multirow{2}{*}{$v_{R}$} & \multirow{2}{*}{$v_{\mathbf{X} \mathbf{i}}$} & \multirow{2}{*}{$\mathbf{v}_{\mathbf{R}, \mathbf{X} \mathbf{i}}$} & $\mathbf{v}_{\mathrm{R}, \mathrm{Xi}}$ & $\mathbf{v}_{\mathrm{R}, \mathrm{Xi}}$ \\
\hline & & & & & $v_{\mathrm{Xi}}$ & $\mathbf{v}_{\mathbf{R}}$ \\
\hline \multirow{6}{*}{ PN-02 } & $\mathrm{b}$ & \multirow{6}{*}{0,0797} & 0,0193 & 0,0100 & $52,0 \%$ & $12,6 \%$ \\
\hline & $\mathrm{d}$ & & 0,0148 & 0,0154 & $104,3 \%$ & $19,4 \%$ \\
\hline & $\mathrm{s}$ & & 0,0714 & 0,0376 & $52,7 \%$ & $47,2 \%$ \\
\hline & $f_{y w}$ & & 0,1300 & 0,0629 & $48,3 \%$ & $78,8 \%$ \\
\hline & $f_{c}$ & & 0,0400 & 0,0208 & $52,0 \%$ & $26,1 \%$ \\
\hline & $\mathrm{A}_{\mathrm{sw}}$ & & 0,0300 & 0,0144 & $47,9 \%$ & $18,0 \%$ \\
\hline \multirow{4}{*}{ EC-2 } & $\mathrm{d}$ & \multirow{4}{*}{0,1528} & 0,0148 & 0,0148 & $100,0 \%$ & $9,7 \%$ \\
\hline & $\mathrm{s}$ & & 0,0714 & 0,0725 & $101,5 \%$ & $47,4 \%$ \\
\hline & $f_{y w}$ & & 0,1300 & 0,1299 & $99,9 \%$ & $85,0 \%$ \\
\hline & $\mathrm{A}_{\mathrm{sw}}$ & & 0,0300 & 0,0300 & $100,0 \%$ & $19,6 \%$ \\
\hline
\end{tabular}


$-v_{\mathrm{Xi}}-$ coefficient of variation of the single variable,

- $v_{R}-$ coefficient of variation of the strength distribution (all variables as random),

- $v_{R, X i}$ - coefficient of variation of the strength distribution (single random variable). Analiza danych zawartych $\mathrm{w}$ tablicy 7 prowadzi do wniosku, że w obu modelach dominującym parametrem jest granica plastyczności stali zbrojenia poprzecznego, choć znaczący wpływ ma również rozstaw strzemion.

The analysis of the data in Table 7 leads to the conclusion that in both models the yield strength of stirrup steel is the dominant parameter, although the stirrup spacing is also a significant factor.

\section{Conclusions}

The performed simulations and the analysis of the results allowed us to formulate the following conclusions:

The mean values of the shear strength simulated according to the analysed models show great variation. The obtained minimum values (the EC-2 model) were 5 to 7 times lower than the maximum values (the $\mathrm{PN}-02$ model).

The values of the partial reliability exponent $\Delta_{R}$ indicate a considerable variation in the level of safety margin. The values calculated for the EC-2 model are in the range of 2.38 to 11.73 , with the smallest for the lower stirrup spacing and greater variability of the steel yield strength and the highest at lower steel yield strength variability and $\cot \theta=2$. For the PN-02 model, extreme values of 4.24 and 31.11 were obtained. Low values are conducive to high variability of the strengths of materials, although trends are so complex that there are exceptions from this general rule.

Analysis of skewness coefficients leads to the conclusion that regardless of the assumed distribution of the compressive strength of compressive concrete, the high variability of the yield strength of steel leads to a low skewness of the shear strength distribution (except for $\mathrm{C} 40 / 50$ concrete). And low variability of the yield strength of steel may lead to a significant increase in the coefficient of skewness and to a simultaneous change of its sign (except for C40/50 concrete and lognormal distribution of its strength, when the values of the coefficient of skewness changes slightly).

In both the models, the dominant parameter is the yield strength of steel and the stirrup spacing is also significant.

The performed analysis does not allow to estimate the total safety margin and the probability of the failure of the construction element as a result of exceeding of the shear strength. This issue may be the subject of further research and analysis covering the parameters of the reliability function $\mathrm{Z}=\mathrm{R}-\mathrm{S}$ distribution.

\section{References}

1. R. Jaskulski, Wplyw wybranych założeń obliczeniowych na zapas bezpieczeństwa zginanych i ściskanych żelbetowych elementów prętowych, wyznaczany metoda Monte Carlo, PhD thesis (Warsaw University of Technology, Płock, 2005)

2. R. Jaskulski, P. Wiliński, Proc. Eng., 153, 232 (2016)

3. R. Jaskulski, P. Wiliński, Proc. Eng., 172, 449 (2017)

4. R. Jaskulski, P. Wiliński, App. Mech. and Mat., 797, 35 (2016)

5. K. Wróbel, XLIX Scientific Conference ,, Krynica 2003”, III, (2003)

6. PN-84/B-03264, Concrete, reinforced concrete and prestressed concrete. Design rules 
7. PN-EN 1992-1-1:2008, Eurocode 2: Design of concrete structures - Part 1-1: General rules and rules for buildings

8. T. Godycki-Ćwirko, Mechanika betonu (Arkady, Warsaw, 1982)

9. T. Godycki-Ćwirko, Ścinanie w żelbecie (Arkady, Warsaw, 1968)

10. M.S. Borishanskiy, Расчет отогнутых стержней и хомутов в изгибаемых железобетонных элементах по стадии разрушения (Stroyizdat, Moscow, 1946)

11. W. Kukulski (Ed.), Obliczanie konstrukcji żelbetowych i sprężonych metoda stanów granicznych wg PN-76/B-03264 (Arkady, Warsaw, 1976)

12. E. Mörsch, Concrete-steel Construction, Authorized translation from the 3rd German ed. (The Engineering News Pub. Co., New York, 1909)

13. H. Kupfer, CEB Bull. d'information, 40, 44 (1964)

14. J. Kobiak, W. Stachurski, Konstrukcje żelbetowe (Arkady, Warsaw, 1995)

15. M. Knauf (Ed.), Podstawy projektowania konstrukcji żelbetowych i sprężonych wedtug Eurokodu 2 (DWE, Wrocław, 2006)

16. F. Casciati, I. Negri, G. Rackwitz, Geometrical Variability in Structural Members and Systems, JCSS Working Document (1991)

17. General Principles on the Specification on Safety Requirements for Structures (German Institute for Standardisation DIN, Beuth, 1981)

18. P. Wiliński, R. Jaskulski, J. Pawlikowski, Probabilistyczna analiza zapasów bezpieczeństwa przekrojów ukośnych w elementach żelbetowych, report from statutory research work $\mathrm{nr}$ 504G/7701/0250/001 (not published, Warsaw University of Technology, Faculty of Building, Mechanics and Petrochemistry, Płock, 2007)

19. J. Pawlikowski, P. Wiliński, R. Jaskulski, Inż. i Bud., 9, 496 (2005) 